\title{
Integrated internal evaluation in a higher education institution
}

\section{Osmo Kauppila*, Tuomo Kinnunen, Janne Harkonen and Jaakko Kujala}

Department of Industrial Engineering and Management, University of Oulu, PL 4610, 90014 Oulun Yliopisto, Finland

E-mail: osmo.kauppila@oulu.fi

E-mail: tuomo.kinnunen@oulu.fi

E-mail: janne.harkonen@oulu.fi

E-mail: jaakko.kujala@oulu.fi

*Corresponding author

\begin{abstract}
Evaluations, both internal and external, have become increasingly common and often compulsory in higher education. Nevertheless, utilising the evaluation results and linking the evaluations to the university's quality assurance system often proves challenging. This article aims to analyse how internal evaluation should be conducted in order to enable integration of internal and external evaluations in higher education. The study is based on analysing an internal evaluation project carried out in a university in Finland. The findings of this study include presenting relevant roles and activities of stakeholders, and key requirements, during different phases of internal evaluation. The key requirements for the success of the integrated internal evaluations identified in this study include: internal evaluation should be based on peer evaluations, evaluators should be trained and given adequate base information to enable critical and logical evaluation and internal evaluation ought to be seen as a collective process with shared ownership.
\end{abstract}

Keywords: internal evaluation; internal auditing; external evaluation; quality assurance; quality management; higher education; evaluation process; evaluation; integration; management in education.

Biographical notes: Osmo Kauppila is a Researcher in the Department of Industrial Engineering and Management at the University of Oulu, Finland. He is responsible for research and education of a wide range of topics in quality management. He holds an MSc in Industrial Engineering and Management. He has worked in both international and national projects regarding quality management in both public and private sectors. His research interests include quality management in higher education, evaluation processes, integrated management systems and statistical methods in quality management.

Tuomo Kinnunen is a Researcher in the Department of Industrial Engineering and Management at the University of Oulu, Finland. He has a Master's degree in Industrial Engineering and Management. He has worked in several international projects. His research interest includes product development and business development covering different angles. 



\begin{abstract}
Janne Harkonen received his Bachelor's degree (1st Class Honours) from University of Greenwich in the UK and both his MSc in Process Engineering and Dr (Tech) in Industrial Engineering and Management, from the University of Oulu, Finland. He has also studied in the University of North Carolina at Wilmington, USA. He has worked for several years in the IT and environmental technology industries. Currently, he is a Postdoctoral Research Fellow at the University of Oulu in Finland. He has authored and co-authored some thirty journal articles, and also a number of other publications.

Jakko Kujala is a Professor of Quality and Project Management at the Department of Industrial Engineering and Management at the University of Oulu, and an Adjunct Professor at Aalto University, Finland. His current research interests include contextual variables in project-based firms and project networks, quality in higher education, business models in project-based firms, and stakeholder management in the project business context. He has authored and co-authored over a hundred refereed research papers.
\end{abstract}

\title{
1 Introduction
}

Evaluations, both external and internal, have become common quality management methodologies to increase competitiveness in both the private and public sectors (Karapetrovic and Willborn, 2001; Svensson and Klefsjö, 2006; Akdere, 2009). Higher education institutions are facing more demands for accountability and conformity (Pillay and Kimber, 2009). In most European countries, higher education institutions are required to participate in external evaluation schemes to support and develop their quality systems (Brennan and Shah, 2000; Harvey, 2002; Schwarz and Westerheijden, 2004).

External evaluations are performed by evaluators from outside the target organisation. Types of external evaluation include external audits, examinations, assessments and reviews (Calvo-Mora et al., 2006; Harvey, 2002; Karapetrovic and Willborn, 2001). The evaluators are either professional evaluators or experts in the field. External evaluations can be compliance-based, or have institution based internal motivations. They can focus on different topics, such as quality systems, performance, or selected process areas (Ehlers, 2009; Koslowski, 2006; Power and Terziovski, 2007; Stensaker et al., 2008).

Internal evaluation is a process of using staff members to evaluate programmes or issues that are directly relevant to an organisation. Internal evaluation can be seen as a form of action research that supports organisational development and planned change (Love, 1998). Forms of internal evaluation include programme evaluations (Love, 1991), selfassessments (Calvo-Mora et al., 2006; Mehralizadeh et al., 2007; Tarí, 2008) and internal audits (Blackmore, 2004; Reid and Ashelby, 2002). It is suggested by many authors that quality-related internal evaluation should be enhancement-led, rather than prescriptive or compliance-based (Beeler, 1999; Blackmore, 2004; Hawkes and Adams, 1995; Kettunen, 2010; Peters, 1998).

Internal evaluation can be used to support external evaluation. Vanhoof and Van Petegem (2007) distinguish three of these supporting roles: a scope-broadening role, an interpretation-promoting role and an implementing role. Strategies for aligning external and internal evaluation include integrating reference models, integrating 
evaluation methodologies, and cross-using them (Karapetrovic and Willborn, 2001). In universities, external evaluation has mostly been separate from other quality system elements. Nevertheless, coupling external evaluation with internal quality assurance methods is seen as potentially beneficial but has received relatively little attention (Stensaker et al., 2008). Our aim was to study the integration of internal and external evaluation in a higher education institution. The following research questions support this aim:

- In what types of activities relevant stakeholders are involved during internal evaluations in higher education institutions?

- What are the key requirements for an internal evaluation process in a university?

The study is based on an internal evaluation project, planned and carried out at the University of Oulu, in Finland. The institutional motivation for the evaluation project behind this study arose from a need of finding synergy between the research assessment exercise (RAE), the university quality system and the Bologna process. The evaluation was linked to an earlier RAE assessment, and the goal was to see how the results of the assessment had been followed up and what kinds of research development mechanisms were used. The results of the evaluation are used to prepare for a national quality audit that is based on the Bologna process.

During the research, scientific literature on evaluation was studied and an internal evaluation process was constructed. The internal evaluation was then carried out and the results were analysed.

\section{Evaluation}

Evaluation always involves judging and valuing phenomena. Its theoretical foundation is somewhat divided, and topics such as the purpose of evaluation and evaluator's role are emphasised differently depending on the author (Alkin, 2004).

According to House and Howe (1999), an evaluator typically establishes criteria of merit, constructs standards, measures performance and compares it to the standards, and synthesises and integrates data into judgements of merit. For this process to be successful, defining appropriate criteria is fundamental. Several possibilities for deriving the criteria exist, such as consulting accepted evaluation models, asking potential clients or other stakeholders and considering institutional viewpoints (House and Howe, 1999). In Scriven's (1991) value logic of evaluation, the mission of the evaluator is the science of valuing, and evaluation is the process of defining value, worth and merit resulting in evaluations. According to Stufflebeam (1985), the fundamental purpose of evaluation is not to prove but to improve. It should boost development, produce understandable data and improve the understanding of the evaluated phenomena.

Patton's $(1997,2002)$ utilisation-focused evaluation primarily focuses on decisionmaking. It is not based on a certain model, method, theory or use, but these factors are tailored to each situation via cooperation with the primary users of the evaluation. This is based on the idea that the primary users of evaluation information are most likely to put it to use if they feel like the owners of the evaluation process and the results. This means that the primary users should have an active part in the process. An evaluation should start from a need recognised by the client (Stufflebeam, 1985; Patton, 
1997). In this way, the evaluator can build the foundation for using the evaluation results at each stage (Patton, 1997, 2002).

Preskill and Torres (1999) present a model for evaluative inquiry as a tool for organisational learning. The main stages of the model are

1 focusing evaluative inquiry

2 carrying out the inquiry

3 applying learning.

In other words, an evaluation process based on evaluative inquiry and utilisation-focused evaluation can be divided into three phases of focusing the evaluation, implementing the evaluation and utilising the evaluation (Preskill and Torres, 1999; Patton, 1997).

Evaluation stakeholders have different roles. Stufflebeam and Shinkfield (2007) describe 12 main roles in evaluation work: client, designer, coordinator, caseworkers, respondents, trainer, researcher, developer, meta-evaluator and specialists in technical support, information and communication. According to Virtanen (2007), the evaluator can act as a judge, as a critical friend, and as a creator of a learning experience for the client or for all evaluation stakeholders. The competence of an evaluator is in conducting the evaluation and reporting the results. The competence of the client is related to commissioning the evaluation and utilising the evaluation information. Being a target of an evaluation also requires skill, such as how to accept criticism and how to use the evaluation results (Virtanen, 2007). In general, the literature identifies the following six main stakeholders for an internal evaluation process: client, facilitator/operator, peer evaluator, target unit of evaluation, decision maker and other members of community (e.g., Blackmore, 2004; Patton, 1997; Virtanen, 2007; Stufflebeam and Shinkfield, 2007).

\section{Research method}

This study is qualitative in nature and based on an internal evaluation carried out at the University of Oulu. The evaluation process is described in detail in Chapter 4. The data was collected through the internal evaluation project containing internal evaluation events that were facilitated, recorded and reported by the authors. The research process is illustrated in Figure 1.

Figure 1 The research process

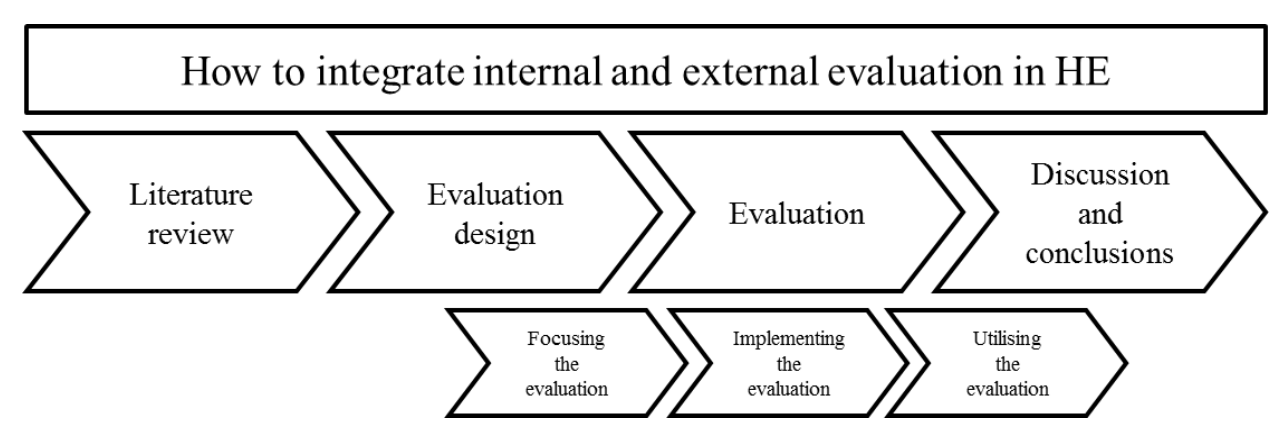


The literature review included topics such as organisational evaluation, internal evaluation and auditing. An outline for the evaluation was proposed as a result of the review. During evaluation design an evaluation model was created based on the evaluation objectives, local and national policy and discussions with the stakeholders. The evaluation was carried out in Finnish and all the relevant material was translated into English. After a pilot evaluation, a focused evaluation model and an implementation plan were established and communicated to the participants.

The evaluation took place as a series of evaluation events. The evaluation events consisted of semi-structured discussions (Merton et al., 1990). The events were recorded and reported, and the reports were verified by the participants. The results of the evaluation were summarised and disseminated at the university level. The research data included observations, notes, recordings, reports and discussions. Findings from the data were discussed against the literature and conclusions were drawn based on this.

\section{The evaluation process}

The purpose of this internal evaluation was to follow up on an external quality assessment, the RAE that took place at the university in 2007 (Jaako and Ruskoaho, 2008; Jaako 2008). During RAE the scientific level of all faculties is evaluated and recommendations are given by external expert panels (Kelly, 2012). The process was activated by a need to enhance research quality assurance at the university, the need arising from the Bologna process (Keeling, 2006). In Finland, higher education institutions are responsible for evaluating their operations, their quality assurance system and how previous assessment results have been utilised. The institutions are obliged to participate in external quality assessments on a regular basis. The results of these assessments are published (Finnish University Law, Ministry of Education, 2007).

The objective of the internal evaluation carried out in 2009 was to identify existing means for developing research, recognising good practices, and to check how the recommendations of RAE had been put into action. The goals of the individual evaluations were to improve research development by providing feedback for research development activities, by sharing the information through peer reviews, and by recognising and sharing good practices.

\subsection{Focusing the evaluation}

At the stage of focusing the evaluation, the contents and focus of the evaluation were created and agreed upon in collaboration with primary stakeholders. The university's quality assurance steering group set a follow-up group for the evaluation. The follow-up group was chaired by the vice rector responsible for the university quality assurance. The evaluation follow-up group and the evaluation assignment itself provided general guidelines on operating and facilitating the evaluation process concerning, for example, the scope of the evaluation and selection of appropriate target units.

A first version of the evaluation questionnaire was created based on the EFQM Excellence Model (2003) and research related clauses of the university quality system. The requirements of national legislation and of the Finnish Higher Education Evaluation Council (2008) were also taken into account. The questionnaire consisted of open questions that were discussed with deans and professors responsible for research 
development activities. Different views and expectations of the evaluation together with any critical aspects of research development at the university were discussed before the evaluation. The purpose of the evaluation, a tentative evaluation model and the evaluation plan were presented to the university community in the form of a two-hour training session. The university bulletin also published a relevant information package.

The evaluation model was then tested by running a pilot, evaluating one of the university departments. Observations from the pilot study showed that the evaluation model was too extensive and complex. Based on the feedback and discussions with the vice rector responsible for scientific research, the model was simplified and focused further on research development and on the activities of the RAE. As a result, a focused, semistructured questionnaire consisting of both open ended and focused questions was created (Appendix 1). The particular focus was set on:

- the mission and goals of unit

- challenges that the unit faces in its research and development

- the degree to which development activities occur in a methodical manner

- development actions occurring in the unit and the results achieved (after the RAE)

- practices related to personnel and post-graduate training

- good practices and recommendations for the development of the unit.

Appropriate target units for the evaluation were selected based on discussions with deans. Resources were tentatively committed to the evaluation. A facilitator initiated communication with the target units regarding arranging the evaluation events and peer evaluations.

\subsection{Implementing the evaluation}

A total of eight evaluation events took place in May 2009 and lasted between one and a half to four hours each. A total of 33 people took part in the events. Roughly, a total of 80 people participated in the process. Three faculty-level committees, one department, two research teams and two research coordination units were evaluated:

Faculty of Technology: Committee of Heads of Departments

Infotech Oulu

Faculty of Natural Sciences: Department of Physical Sciences

Faculty of Education: Learning and Educational Technology Research Unit

Biocenter Oulu

Oulu Business School: Research group "Growth strategies of high technology enterprises"

Faculty of Medicine: Postgraduate education committee.

Faculty of Social Sciences: Research committee

The variety in types of units evaluated aimed to enrich discussion and provide data on the appropriateness of the evaluation model. The events were attended by personnel from the target unit, peer evaluators from other units and the main researcher, who acted as the facilitator and the chairman of each evaluation event. The participants were individuals 
responsible for research development in their own units. The events were carried out using the developed questionnaire and by encouraging and engaging participants in conversation.

Successful implementation of an evaluation event requires practical preparations such as booking facilities, composing schedules and communicating them. In this case, the facilitator also did the preliminary acquisition of information of the target units from open access sources, in particular home pages, university documents and RAE reports. The collected pre-information was sent to the participants. The nomination of peer evaluators was done within the target units.

The peer evaluation arrangements were mostly successful, despite of some minor difficulties in recruiting voluntary peer evaluators. Nevertheless, the evaluation events were mostly well received by the participating units. The positive reception was indicated by the enthusiastic discussion following the events and through spontaneous feedback, such as the following message via e-mail:

"Sincere thanks. The evaluation debate and the unit report were much more useful I could predict. The report supports our work and helps us to see our situation and development trends. - - I hope that we can continue peer evaluation like this at the University."

The positive experiences during the peer evaluations indicate the usefulness of the internal evaluation process. The evaluation proved more successful in smaller and more focused units where a deep level of discussion on the topic occurred. In larger units, the discussion often had a political focus on the operational environment and competition for funds. However, even in larger units, the participants found the evaluation beneficial.

\subsection{Utilisation of the evaluation}

Cross-organisational discussion in the form of using peer-evaluators was experienced as one of the most rewarding parts of internal evaluation. The evaluation events at their best functioned as workshops and engaged participants in discussions concerning good practices, improvement needs and challenges. The usefulness of the evaluation seems to depend largely on the unit representatives as they often are responsible for development actions in their units. Good practices are often based on individual field-specific and tacit knowledge, and thus transferring them can be challenging.

Table 1 Excerpts from unit reports

Development actions made at units

"Department has changed over from subject-based to research team-based organisation structure and created research strategy as a reaction to feedback from $R A E$ "

"Research team has re-defined policy related to recruitment and focusing"

"Research coordination unit has decided to conduct a future grand challenges - lecture series and allocated resources for it"

"Faculty has removed division into departments and centralised resource allocation to the faculty"

The evaluation events were recorded and reported based on audio recordings and notes by the facilitator. Analysing the material was twofold, resulting in unit specific reports and a concluding report. The unit reports were sent back to the units to be reviewed for 
accuracy. Excerpts from the unit reports are illustrated in Table 1 and a sample evaluation summary is presented in Appendix 2. According to the feedback, the reports corresponded well with the content and atmosphere of the evaluation events.

The concluding report included an informative summary of the research development activities and suggested improvement actions and good practices for the evaluated units (Kinnunen, 2009). The final report aimed for a creative synthesis and an informative summary through inductive analysis, as Patton (2002) recommends. University level improvement suggestions were as follows:

1 The need for statistical consulting and methodological know-how throughout the university should be surveyed and improved. The university should ensure that consultation regarding methods is available to all research projects regardless of faculty.

2 To elevate the scientific level of research, funding for basic research should be increased and by enhancing the doctoral level researcher base.

3 The university should maintain a university-wide research quality assessment process that is discipline specific and based on international criteria.

4 The RAE feedback should be paid further attention to, both unit specific and general university level recommendations. Plenty of room for learning and improvement based on the recommendations still exist.

5 The university administration should extend the rational basis, monitoring and measurement of research improvement activities and make the information more visible and real-time.

A university-wide seminar was arranged on the result of the internal evaluation and the evaluation report was passed to the vice rectors, the university quality steering group and the university research council.

\section{Findings and discussion}

The gained experience with the evaluation process indicates that the roles of evaluation stakeholders must be taken into account to succeed in integrating internal and external evaluation in higher education. Each organisation that was evaluated has its own special features, opinion leaders, culture and sub-cultures making the environments case-specific (Patton, 2012). Internal evaluation can be seen as a collective process, in which the evaluation stakeholders work together to reach the common goal of the evaluation aside their individual goals. Table 2 presents evaluation process stakeholders as found in the literature review and their definitions as observed during the carried out evaluation process.

The roles and activities of the stakeholders can change during internal evaluations. Table 3 illustrates the roles and activities of different stakeholders as observed during the evaluation process. 
Table 2 Internal evaluation stakeholders

\begin{tabular}{|c|c|}
\hline Stakeholder & Definition \\
\hline Client & $\begin{array}{l}\text { Board, a vice rector or an appropriate council that has the authority to } \\
\text { set a purpose, scope and resources for internal evaluation and to } \\
\text { nominate competent facilitator/operator(s). }\end{array}$ \\
\hline Facilitator/operator & $\begin{array}{l}\text { A vital resource of the process in practice, framing the basis and logic } \\
\text { of the evaluation. The role of the facilitator/operator is based on the } \\
\text { idea that internal evaluations should be conducted by staff who are } \\
\text { engaged in the activities that are under evaluation. The full-time } \\
\text { facilitator/operator ensures that operations are as smooth as possible, } \\
\text { decreasing required resources. }\end{array}$ \\
\hline Peer evaluator & $\begin{array}{l}\text { The essence of internal evaluation. Peer evaluators do not need to be } \\
\text { expert evaluators as long as they are familiar with the environment, } \\
\text { understand the evaluation purpose, the basics of evaluation and the } \\
\text { evaluated phenomena, and are willing to contribute. }\end{array}$ \\
\hline $\begin{array}{l}\text { Target unit of } \\
\text { evaluation }\end{array}$ & $\begin{array}{l}\text { Should be able to contribute to and benefit from the evaluation with } \\
\text { regards to its purpose, scope and the desired extent of evaluation. }\end{array}$ \\
\hline Decision-maker & $\begin{array}{l}\text { Deans and vice-deans at universities are the key to the internal } \\
\text { environment and are thus the primary partners for the facilitator at the } \\
\text { focus stage of evaluation. }\end{array}$ \\
\hline $\begin{array}{l}\text { Other members of } \\
\text { community }\end{array}$ & $\begin{array}{l}\text { Not directly involved in the internal evaluation, but are familiar with } \\
\text { target unit or other similar units can benefit from the results, are also } \\
\text { stakeholders. }\end{array}$ \\
\hline
\end{tabular}

Table 3 The roles and activities of stakeholders during evaluation

\begin{tabular}{|c|c|c|c|}
\hline & $\begin{array}{l}\text { Focusing the } \\
\text { evaluation }\end{array}$ & $\begin{array}{c}\text { Implementing the } \\
\text { evaluation }\end{array}$ & $\begin{array}{l}\text { Utilising the } \\
\text { evaluation }\end{array}$ \\
\hline Client & $\begin{array}{l}\text { Acts as an activator, } \\
\text { sets the purpose, scope, } \\
\text { resources and time } \\
\text { frame }\end{array}$ & $\begin{array}{l}\text { Sets guidelines, follows } \\
\text { progression }\end{array}$ & $\begin{array}{l}\text { Assesses the success of } \\
\text { the evaluation. } \\
\text { Communicates results to } \\
\text { the decision-makers }\end{array}$ \\
\hline $\begin{array}{l}\text { Facilitator/ } \\
\text { operator }\end{array}$ & $\begin{array}{l}\text { Creates basis for the } \\
\text { entire evaluation } \\
\text { process in collaboration } \\
\text { with stakeholders }\end{array}$ & $\begin{array}{l}\text { Arranges framework. } \\
\text { Creates positive } \\
\text { atmosphere for } \\
\text { evaluation }\end{array}$ & $\begin{array}{l}\text { Reports results. } \\
\text { Disseminates results and } \\
\text { promotes their use in a } \\
\text { wider context }\end{array}$ \\
\hline Peer evaluator & $\begin{array}{l}\text { Selected and trained } \\
\text { personnel. Committed } \\
\text { to subject }\end{array}$ & $\begin{array}{l}\text { Carries out the } \\
\text { evaluation transparently } \\
\text { and critically in a } \\
\text { development-oriented } \\
\text { manner }\end{array}$ & $\begin{array}{l}\text { Learns during the } \\
\text { process. Utilises the } \\
\text { results in their own work }\end{array}$ \\
\hline $\begin{array}{l}\text { Target unit of } \\
\text { evaluation }\end{array}$ & $\begin{array}{l}\text { Selected. Commitment } \\
\text { starts through } \\
\text { collaboration }\end{array}$ & $\begin{array}{l}\text { Active participation of } \\
\text { responsible people. } \\
\text { Liberty to speak and ask } \\
\text { questions }\end{array}$ & $\begin{array}{l}\text { Develops own processes } \\
\text { and takes actions based } \\
\text { on feedback and learning }\end{array}$ \\
\hline $\begin{array}{l}\text { Decision- } \\
\text { maker }\end{array}$ & $\begin{array}{l}\text { Involved in the process } \\
\text { and collaboration }\end{array}$ & $\begin{array}{l}\text { Informed about } \\
\text { progression }\end{array}$ & $\begin{array}{l}\text { Communicates results ate } \\
\text { the organisational level. } \\
\text { Coordinates development } \\
\text { at the organisational level }\end{array}$ \\
\hline $\begin{array}{l}\text { Other } \\
\text { members of } \\
\text { community }\end{array}$ & Informed & Informed & $\begin{array}{l}\text { Informed about results } \\
\text { and learnings }\end{array}$ \\
\hline
\end{tabular}


Integrating internal evaluation starts with a need by the client to follow up on a previous external evaluation. In the analysed case, the client was responsible for the quality assurance system of the university. The facilitator was recruited to further focus the evaluation and to work towards committing the users of evaluation. Active participation by the primary users, the peer evaluators and target units, was experienced critical for the success of integrated internal evaluation. The facilitator and the client communicated the evaluation results to the secondary users - the decision-makers and other members of community. Ideally the secondary users would utilise the evaluation results on both organisational and individual levels.

\subsection{Key requirements for integrated internal evaluation}

During the research, several issues critical to integrating internal and external evaluation in the analysed university were recognised. These recognised key requirements are listed and compared with earlier research in Table 4.

Table 4 Key requirements for integrated internal evaluation

\begin{tabular}{|c|c|c|}
\hline & Key requirement & Authors' findings \\
\hline \multirow[t]{5}{*}{$\begin{array}{l}\text { Focusing the } \\
\text { evaluation }\end{array}$} & \multicolumn{2}{|c|}{$\begin{array}{l}\text { The purpose and the scope are set and Internal evaluation should be } \\
\text { described by an authority } \\
\begin{array}{ll}\text { (c.f. Svensson and Klefsjö, 2006) } & \text { management to function as top-down }\end{array}\end{array}$} \\
\hline & \multicolumn{2}{|c|}{ Basis and logic for internal evaluation quality assurance } \\
\hline & $\begin{array}{l}\text { is created in collaboration with the } \\
\text { intended users (Patton, 1997) }\end{array}$ & \multirow{2}{*}{$\begin{array}{l}\text { Transparency and adaption to local } \\
\text { settings forms the basis for trust and } \\
\text { later utility. Involving people who can } \\
\text { influence the utilisation of the results } \\
\text { was found important. }\end{array}$} \\
\hline & \multirow{2}{*}{$\begin{array}{l}\text { Primary stakeholders are recognised, } \\
\text { selected and involved in process by } \\
\text { the facilitator (e.g., Preskill and } \\
\text { Torres, 1999; Patton, 1997; Ehlers, } \\
\text { 2009) }\end{array}$} & \\
\hline & & $\begin{array}{l}\text { Internal evaluation should be designed } \\
\text { to be a collective process with shared } \\
\text { ownership }\end{array}$ \\
\hline \multirow[t]{4}{*}{$\begin{array}{l}\text { Implementing the } \\
\text { evaluation }\end{array}$} & $\begin{array}{l}\text { The facilitator arranges a framework } \\
\text { and creates a positive atmosphere for } \\
\text { the evaluation (Morabito, 2002) }\end{array}$ & $\begin{array}{l}\text { Evaluation should be seen as a chance } \\
\text { to develop and learn. All involved } \\
\text { parties need to make an effort for this }\end{array}$ \\
\hline & \multirow{2}{*}{$\begin{array}{l}\text { Peer evaluators act transparently and } \\
\text { critically in a development-oriented } \\
\text { manner (Costa and Kallick, 1993; } \\
\text { Andreu et al., 2003; Dixon, 2009) }\end{array}$} & to happen. \\
\hline & & $\begin{array}{l}\text { Internal evaluation should be based on } \\
\text { peer evaluation, as it is experienced to } \\
\text { be a fair method by the participants. }\end{array}$ \\
\hline & $\begin{array}{l}\text { Target unit participants are people } \\
\text { responsible for the evaluation area } \\
\text { and have liberty to discuss it (c.f. } \\
\text { Svensson and Klefsjö, 2006) }\end{array}$ & $\begin{array}{l}\text { People responsible for an area being } \\
\text { evaluated should participate to exploit } \\
\text { the evaluation findings at a local level }\end{array}$ \\
\hline \multirow[t]{3}{*}{$\begin{array}{l}\text { Utilising the } \\
\text { evaluation }\end{array}$} & $\begin{array}{l}\text { Target units develop their own } \\
\text { processes and actions based on } \\
\text { feedback and learning (Patton, 1997) }\end{array}$ & $\begin{array}{l}\text { The primary effect of the internal } \\
\text { evaluation is experienced locally. } \\
\text { Each unit should be considered as }\end{array}$ \\
\hline & \multirow{2}{*}{$\begin{array}{l}\text { Decision-makers disseminate the } \\
\text { evaluation findings and coordinate } \\
\text { development at organisational level } \\
\text { (Preskill and Boyle, 2008) }\end{array}$} & |ue \\
\hline & & $\begin{array}{l}\text { Internal evaluation should be } \\
\text { integrated with quality assurance and } \\
\text { management systems to function as } \\
\text { bottom-up quality assurance }\end{array}$ \\
\hline
\end{tabular}


During focusing the evaluation the facilitator, client and decision-makers collaborate and make decisions considering the recognised need, described purpose and scope of the evaluation. These situational and contextual factors should guide the implementation of the evaluation. Peer evaluators need to be trained to ensure that they understand the evaluation purpose, their role as a critical friend (Blackmore, 2004; Costa and Kallick, 1993; Dixon, 2009), how the evaluation is planned to take place, and how to prepare for an evaluation.

Communication during focusing the evaluation was experienced to have a significant role in preparing peer evaluators and target units for the evaluation. This was seen to enhance creation of positive evaluation experiences and utilisation of results. Relevant information about the target units, especially results of the previous external evaluation and actions taken afterwards, must be provided beforehand to enable critical and logical peer evaluation.

When implementing the evaluation the facilitator is responsible for creating an environment in which successful peer evaluation can take place. Each evaluation event should be treated and reported as unique in order to maximise the local development and learning effects. Data collection and reporting should serve the needs and preferences of both primary and secondary users in order to fully utilise the evaluation results (Patton, 1997, 2002).

The basis for utilising the evaluation is constructed throughout the evaluation process. The primary effects of internal evaluation are local, ones that can be achieved when a target unit perceives ownership of the process and experiences the evaluation as fair and useful. The secondary level of use of the results includes actions by decision makers and peer evaluators in their own organisational contexts, and by facilitators to improve the evaluation process.

\section{Conclusions}

Internal and external evaluations have become common quality management practices for increasing the competitiveness in both the private and public sectors. These types of evaluations are typically conducted separately without cross analysing the obtained results. This article aims to analyse how internal evaluation should be conducted in order to enable integration of internal and external evaluations in higher education. In particular, this article analyses what types of requirements are relevant for an internal evaluation process to ensure adequate integration to external evaluations, and support quality assurance.

Internal evaluation processes in higher education institutions can be divided into three phases of focusing the evaluation, implementing the evaluation, and utilising the evaluation results. Stakeholders of internal evaluations are involved in various activities during the process. The stakeholders include: client, facilitator, peer evaluator, target unit of evaluation, decision-maker, and other community members. The roles of client and facilitator are central when focusing the evaluation. The client acts as an activator who sets the purpose, scope, resources, and time frame for the process. Facilitator creates the basis for the evaluation process in collaboration with the stakeholders. During implementing the evaluation, the facilitator makes the practical arrangements and works to create a positive atmosphere for the evaluation. Active participation by the peer evaluators and target units is critical for the success of integrated internal evaluation. 
These stakeholders are also key users of the evaluation results. During utilising the evaluation results, the client and the facilitator work to deliver the results to decision makers and other community members. Decision makers coordinate organisational development activities.

The key requirements of internal evaluation process can be analysed through the three phases. During focusing the evaluation, situational and contextual factors of the evaluation as well as the local context are vital and must be taken into account. These factors can act as a guide for implementing the evaluation. Training the peer evaluators is important as they must have adequate understanding over their role and the evaluation purpose. Peer evaluators must have access to the results of previous external evaluations, and other relevant information, to enable critical and logical evaluation. During implementing the evaluation, it is vital that each evaluation event is treated and reported as a unique case in order to maximise local development and learning. Data collection and reporting should be in such a format that they serve the needs and preferences of the evaluation stakeholders. When utilising the evaluation results, one of the key aspects is perceived ownership by the unit under evaluation, as the primary effect is local. One of the key requirements for the success of the evaluation is that the decision makers take the responsibility over the evaluation results and take relevant actions.

People involved in quality assurance in higher education institutions as well as researchers interested in the topic may benefit from the findings of this study. Internal evaluation can be used to integrate external evaluation with the quality system of a higher education institution. Internal evaluation as described in this research can be used to supplement and support, but not to substitute quality assurance and management of a university.

The limitations of this study include analysing one internal evaluation process in one university. The application of the findings may be linked to the context to a degree, potentially limiting their applicability. In addition to addressing the above limitations future study could include analysing external evaluation processes from a similar perspective. Analysing the experiences of individual actors more deeply would also be an interesting topic for further study.

\section{References}

Akdere, M. (2009) 'Quality management integration in education: a model of practice for performance excellence in education', International Journal of Management in Education, Vol. 3, Nos. 3-4, pp.291-301.

Alkin, M.C. (Ed.) (2004) Evaluation Roots: Tracing Theorists' Views and Influences, Sage Publications, Inc., Thousand Oaks, California.

Andreu, R., Canós, L., de Juana, S., Manresa, E., Rienda, L. and Tarí, J.J. (2003) 'Critical friends: a tool for quality improvement in universities', Quality Assurance in Education, Vol. 11, No. 1, pp.31-36.

Beeler, D.L. (1999) 'Internal auditing: the big lies', Quality Progress, Vol. 32, No. 5, pp.73-78.

Blackmore, J.A. (2004) 'A critical evaluation of academic internal audit', Quality Assurance in Education, Vol. 12, No. 3, pp.128-135.

Brennan, J. and Shah, T. (2000) 'Quality assessment and institutional change: experiences from 14 countries', Higher Education, Vol. 40, pp.331-349.

Calvo-Mora, A., Leal, A. and Roldán, J.L. (2006) 'Using enablers of the EFQM model to manage institutions of higher education', Quality Assurance in Education, Vol. 14, No. 2, pp.99-122. 
Costa, A. and Kallick, B. (1993) 'Through the lens of a critical friend', Educational Leadership, Vol. 51, No. 2, pp.49-51.

Dixon, S. (2009) 'Critical friend: the performance audit function of the Grimsby institute', Journal of Research and Scholarly Output, Vol. 3, pp.15-26.

EFQM Excellence Model: Finnish Translation (2003) Laatukeskus, Helsinki.

Ehlers, U.D. (2009) 'Understanding quality culture', Quality Assurance in Education, Vol. 17, No. 4, pp.343-363.

Finnish Higher Education Evaluation Council (2008) Audits of Quality Assurance Systems of Finnish Higher Education Institutions. Audit Manual for 2008-2011, Finnish Higher Education Evaluation Council, Tampere.

Harvey, L. (2002) 'Evaluation for what?', Teaching in Higher Education, Vol. 7, No. 3, pp.245-263.

Hawkes, L.C. and Adams, M.B. (1995) 'Total quality management and the internal audit: empirical evidence', Managerial Auditing Journal, Vol. 10, No. 1, pp.31-36.

House, E.R. and Howe, K.R. (1999) Values in Evaluation and Social Research, Sage Publications, Thousand Oaks.

Jaako, J. (2008) Research Assessment Exercise 2007, Research Evaluation of the University of Oulu, Panel Reports, Oulun yliopistopaino, Oulu.

Jaako, J. and Ruskoaho, H. (2008) Research Assessment Exercise 2007, Research Evaluation of the University of Oulu, Summary Report, Oulun yliopistopaino, Oulu.

Karapetrovic, S. and Willborn, W. (2001) 'Audit and self-assessment in quality management: comparison and compatibility', Managerial Auditing Journal, Vol. 16, No. 6, pp.366-377.

Keeling, R. (2006) 'The Bologna process and the Lisbon research agenda: the European commission's expanding role in higher education discourse', European Journal of Education, Vol. 41, No. 2, pp.203-223.

Kelly, A. (2012) 'Ranking the outcomes from the assessment of research in the UK', International Journal of Management in Education, Vol. 6, Nos. 1/2, pp.74-87.

Kettunen, J. (2010) 'Cross-evaluation of degree programmes in higher education', Quality Assurance in Education, Vol. 18, No. 1, pp.34-46.

Kinnunen, T. (2009) The Improvement of Research Activities in the University of Oulu - A Summary of Internal Evaluation (in Finnish), University of Oulu, Oulu.

Koslowski III, F.A. (2006) 'Quality and assessment in context: a brief review', Quality Assurance in Education, Vol. 14, No. 3, pp.277-288.

Love, A.J. (1991) Internal Evaluation: An Essential Tool for Human Service Organizations, Sage Publications, Newbury Park.

Love, A.J. (1998) 'Integrating evaluation and social work practice', Scandinavian Journal of Social Welfare, Vol. 7, pp.145-151.

Mehralizadeh, Y., Pakseresht, M.J., Baradaran, M. and Sakineh, S. (2007) 'The dilemma of internal evaluation in higher education: a longitudinal case study', Quality Assurance in Education, Vol. 15, No. 3, pp.352-368.

Merton, R., Fiske, M. and Kendall, P. (1990) The Focused Interview: A Manual of Problems and Procedures, 2nd ed., The Free Press, New York, NY.

Ministry of Education (2007) Education and Research 2007-2012: Development Plan, Ministry of Education, Helsinki.

Morabito, S.M. (2002) 'Evaluator roles and strategies for expanding evaluation process influence', American Journal of Evaluation, Vol. 23, No. 3, pp.321-330.

Patton, M.Q. (1997) Utilization-Focused Evaluation: The New Century Text, Sage Publications, Thousand Oaks. 
Patton, M.Q. (2002) Qualitative Research and Evaluation Methods, Sage Publications, Thousand Oaks.

Patton, M.Q. (2012) 'Contextual pragmatics of valuing', New Directions for Evaluation, Vol. 133, pp.97-108.

Peters, J. (1998) 'Some thoughts on auditing', The TQM Magazine, Vol. 10, No. 1, pp.4-5.

Pillay, H.K. and Kimber, M. (2009) 'Quality assurance in higher education: for whom and of what?', International Journal of Management in Education, Vol. 3, Nos. 3/4, pp.270-281.

Power, D. and Terziovski, M. (2007) 'Quality audit roles and skills: perceptions of non-financial auditors and their clients', Journal of Operations Management, Vol. 25, No. 1, pp.126-147.

Preskill, H. and Boyle, S. (2008) 'A multidisciplinary model of evaluation capacity building', American Journal of Evaluation, Vol. 29, No. 4, pp.443-459.

Preskill, H. and Torres, R.T. (1999) Evaluative Inquiry for Learning in Organizations, Sage Publications, Thousand Oaks.

Reid, K. and Ashelby, D. (2002) 'The Swansea internal quality audit processes: a case study', Quality Assurance in Education, Vol. 10, No. 4, pp.237-246.

Schwarz, S. and Westerheijden, D.F. (Eds.) (2004) Accreditation in the Framework of Evaluation Activities. Current Situation and Dynamics in Europe, Kluwer Academic Press, Dordrecht.

Scriven, M. (1991) Evaluation Thesaurus, Sage Publications, Newbury Park.

Stensaker, B., Brandt, E. and Solum, N.H. (2008) 'Changing systems of external examination', Quality Assurance in Education, Vol. 16, No. 3, pp.211-223.

Stufflebeam, D.L. (1985) Systematic Evaluation: A Self-Instructional Guide to Theory and Practice, Kluwer-Nijhoff, Boston.

Stufflebeam, D.L. and Shinkfield, A.J. (2007) Evaluation Theory, Models, \& Applications, JosseyBass, San Francisco.

Svensson, M. and Klefsjö, B. (2006) 'TQM-based self-assessment in the education sector: experiences from a Swedish upper secondary school project', Quality Assurance in Education, Vol. 14, No. 4, pp.299-323.

Tarí, J.J. (2008) 'Self-assessment exercises: a comparison between a private sector organization and higher education institutions', International Journal of Production Economics, July, Vol. 114, No. 1, pp.105-118.

Vanhoof, J. and Van Petegem, P. (2007) 'Matching internal and external evaluation in an era of accountability and school development: lessons from a Flemish perspective', Studies in Educational Evaluation, Vol. 33, No. 2, pp.101-119.

Virtanen, P. (2007) Arviointi: arviointitiedon luonne, tuottaminen ja hyödyntäminen, in Finnish. Edita, Helsinki. 


\section{Appendix 1 The evaluation questionnaire}

Challenges in research development - a questionnaire for evaluating research development actions in the University of Oulu, spring 2009

1 What creates a feeling of success in research? When did you last experience this?

2 What causes feelings of frustration?

3 What is scientific top level research like? "A high international level"

a What are the required conditions for a top level research environment?

b What kind of organisational culture, leadership, management and policy supports top level research?

4 How can long term top level research be achieved with short term funding?

5 What is the current state of the unit's research activity?

A What are the goals of research activity? - Goal and result orientation

1 What are the goals for research in our unit? How do these correspond to the legal requirements of "high international level"

2 What does our organisation want to be?

3 How are our research activities and results communicated externally? "able to withstand critical observation"

a What are the most important publication forums of the unit? What publications should we strive for?

b Does the unit have a publication plan and goals? What are they like?

4 How do research activities serve the society?

B How to reach the goals? - Critical success factors

1 In which areas do we need to succeed and to be good at?

2 What are the biggest challenges and causes of delay in research activity?

3 How is success measured in research?

C How does research work take place? - Processes and activities

1 What does research entail? What are the core and supporting processes or functions of research?

a How are they planned and managed? Is this a systematic process?

b How is research conducted and supervised? Give some examples. Describe the unit's dissertation process.

2 For whom is the research done for? - Customers / target group

D Who are the researchers? - Personnel

1 On what basis, from where and how are researchers and research personnel recruited? 
a What kind of competence does the unit need to reach its goals now and in the future?

b How can the most suitable persons be reached and recruited?

2 What is the role of postgraduate students regarding research activities?

a How are postgraduate students guided and supported?

b Is there a training system for new researchers? How does it function? How does it meet its requirements?

3 How are skills of the personnel maintained and developed?

a How is researcher competence improved?

b Is there a career path system in place? How does it function? How does it meet its requirements?

4 How is the involvement of the personnel encouraged?

5 How are the personnel empowered?

6 How are the personnel rewarded?

7 How does dialogue take place in the organisation?

8 How is internal communication organised and how does it take place? Does it reach its target group?

E With whom and where does research take place? - Cooperative relationships and networking

1 Who are the research partners of the unit?

a How are research relationships managed?

b In what kinds of national and international research projects is the unit involved in?

c Does researcher exchange take place at the unit?

2 What are the goals of cooperation and networking, and what has been achieved?

F With what is the research done? - Resources, tools and infrastructure

1 What are the most central research resources? How are they managed?

2 Whave teaching responsibilities?

3 How are research results linked to undergraduate education? "The highest level education related to research"

4 How are undergraduate students involved in the unit's research?

5 What is the role of external funding in research activities?

a How are external funding relationships managed? 
6 What sorts of infrastructure, technology and tools does the unit's research require?

7 How is research documentation and data managed?

a Which tools and methods does the unit use?

G What guides research? - Organisational policy, strategy and ethics

1 What guides research in the organisation?

a Does the unit have a strategy? If so, how and by whom has it been created?

2 What is the research policy of the organisation?"according to ethical principles and good scientific practice"

3 How is policy and strategy communicated and put to action?

$H \quad H o w$ are research activities and the research organisation led? Leadership

1 What is good academic leadership like? What differentiates it from e.g. corporate leadership?

2 According to the EFQM model: "Excellence is visionary and inspirational leadership, coupled with constancy of purpose.." and "Excellence is managing the organisation through a set of interdependent and interrelated systems, processes and facts."

a Are these statements relevant to leadership in academic research?

b Are these statements relevant in the leadership of a research organisation?

3 What risks are related to research activities and organisations? How are they managed?

I How is research developed? - Research development activities

1 What is research development currently based on?

a Have the actors and roles been defined? How?

i What is the role and significance of the research development council?

b What processes and activities are in place for maintaining and improving research quality?

i Is research developed systematically and in a planned manner? How?

2 How do we recognise development areas?

3 What research development actions have been taken or have been planned?

a What could be done in the future? 
J What are we doing well? What could we do even better? - Reflection

1 What is our unit good at? What good practices do we have? In which areas could others learn from us?

2 Where could we improve? In which areas could we learn from others?

3 What will the unit's research activities be like in one, three or five years? What could it be in the future?

4 What is meant by research quality? How is research quality in the unit ensured now and in the future? 


\section{Appendix 2 Evaluation summary - example}

\section{Evaluation report summary - research development}

Date

Location

Time
May 15th 2009

Room FY254-2

13:00-15:00

Evaluation target Department of Physical Sciences

The Department of Physical Sciences has the goal of being internationally recognised highlevel research unit and a quality educator. At the departmental level, deputy head of research is responsible for research, and also acts as the chairman of the department's research development working group (RDWG). Individual heads of research groups are responsible for research and education in their respective focus areas. The role of the RDWG, established in 2008, requires further clarification. To date RDWG has mainly focused on issues dealing with appointment structures and infrastructure acquisitions. Prior to 2008, the department professors were responsible for similar activities. For practical reasons, the department is planning to reduce the size of RDWG from current 14 members of personnel. Nevertheless, currently any issues with more significance are still dealt with in a department council and at the faculty level. Assuring the research quality takes place mainly through international peer-reviewed publications. Publications and their impact factors have been followed for about 15 years, also citations are tracked.

One of the key challenges at the departmental level is the diversity of research. The department's research areas have very little in common when the research interests range from studying galaxies to cell membrane proteins. Recruitment at all levels is seen as a challenge due to the Northern location of the university. Another challenge is seen to lie in the department's scattered history, the department being a collection of different types of units and the resulting versatility in the ways of working. Individual research groups are challenged by the work that comes with attempting to keep up, and to be successful in competitive research fields.

Since the RAE in 2007 the department has experienced structural and operational changes. The results of RAE have been used as required leverage in change and development, while the outside opinions are seen to have reinforced ideas and the awareness on development needs. The renewal has been guided by a research development plan, according to which the department has moved from a subject based structure to a research group based structure. A research strategy has also been created as a reaction to RAE feedback. For example, the new research strategy includes a target to increase the number of post-doctoral researchers to aid in creating sufficiently strong research groups. Developing the personnel structure and the principles of allocating internal funding are seen as the main tools for improving research. Forming the strategy was initiated based on discussions among the head of department and the professors. Subsequently the department decided that the size of the department necessitates for separate vice department heads responsible for education and research. Research strategy was developed further by the department head and the vice head responsible for research. Departmental meetings for teaching and research staff are used for discussion and feedback on ideas. The department is still undergoing renewal, resulting in the negative side effect of the process taking resources that could be used for actual research work.

Result orientation has increased significantly, as in the future; tenure positions will be awarded based on the success of the research groups. The changes are seen to have clearly opened up the discussion. The earlier structure was experienced inflexible as it did not allow transferring personnel resources from one research area to another. Nevertheless, it is too early to evaluate the results of the new operating model. The department expects the weaker research groups to take actions on their weaknesses and strive for improvement.

Good practices that were recognised include: research group oriented post graduate studies, identifying the most potential candidates for graduate studies, and recruiting them early to work at the department and in research groups. Also, arranging regular research seminars were identified as a good practice. Research oriented teaching, research group based organisation and commitment of personnel to research were identified as good 
practices. The department's model for calculating results was recognised as a good practice due to its impact in raising the result awareness amongst personnel, and due to the resulting motivation boost.

Improvement recommendations included reinforcing the research groups with postdoctoral researchers and pooling resources to maintain sufficiently strong research groups (a professor and two senior researchers). Promoting the common awareness of research findings and local visibility were also seen as issues of future focus. The department was also given a recommendation to further improve the level of its publications and strive for higher level publication forums. 